\title{
Comparison of tank silt and farm yard manures in relation to soil water retention capacity and soil fertility in redgram in alfisol of NSP left canal command area
}

\author{
M. RAJESHWAR* AND V. RAMULU \\ Acharya N.G. Ranga Agricultural University A.P Water Management Project, Agricultural Research Station, \\ Garikapadu, KRISHNA(A.P.) INDIA (Email : rajeshoct31naik@gmail.com )
}

\begin{abstract}
On farm field experiment on effect of soil amendments in relation to soil water retention capacity and soil fertility in redgram were taken up in Alfisols of NSP left canal command area during Kharif 2006 and Kharif 2007 at pilot area Ganapavaram of Nagarjuna Sagar Project left canal command under A.P. water management project funded by FAO. The trial was carried with the farmers participatory mode to study the impact of application of tank silt and farm yard manure as soil amendments in relation to soil water retention capacity and soil fertility and on crop yield of redgram. The five treatments consisted of 5t FYM/ha, 10t FYM/ ha, 20t tank silt/ha, 30t tank silt/ha and RDF. Application of $20 \mathrm{t}$ of tank silt + RDF and $30 \mathrm{t}$ of tank silt + RDF application recorded highest grain yield of $2290 \mathrm{~kg} \mathrm{ha}^{-1}$ and $2180 \mathrm{~kg} \mathrm{ha}^{-1}$ during Kharif, 2006 and $20 \mathrm{t}$ of tank silt + RDF recorded highest grain yield of $2280 \mathrm{~kg} / \mathrm{ha}$ followed by application of $30 \mathrm{t}$ of tank silt+ RDF $(2130 \mathrm{~kg} / \mathrm{ha})$ and application of $10 \mathrm{t}$ of FYM+ RDF $(2040 \mathrm{~kg} / \mathrm{ha})$ during Kharif, 2007, respectively. Post harvest soil analysis revealed that the organic carbon content was high in $10 \mathrm{t} F Y M+R D F$ where as the application of increased tank silt recorded increase in water holding capacity during the both the years.
\end{abstract}

Key Words : Soil amendments, Soil fertility, Redgram, Canal command

View Point Article : Rajeshwar, M. and Ramulu, V. (2015). Comparison of tank silt and farm yard manures in relation to soil water retention capacity and soil fertility in redgram in alfisol of NSP left canal command area. Internat. J. agric. Sci., 11 (2) : 346-349.

Article History : Received : 24.12.2014; Accepted : 25.05.2015

\footnotetext{
* Author for correspondence
} 